\title{
Pengaruh Good Corporate Governance dan Ukuran Perusahaan Pada Manajemen Laba
}

\author{
I Made Karma Cahyadi ${ }^{1}$ \\ I Made Mertha ${ }^{2}$ \\ ${ }^{1,2}$ Fakultas Ekonomi dan Bisnis Universitas Udayana (Unud), Bali, Indonesia \\ e-mail: karmacahyadi@gmail.com
}

\begin{abstract}
ABSTRAK
Tujuan dari penelitian ini adalah untuk mengetahui pengaruh good corporate governance dan ukuran perusahaan pada manajemen laba di perusahaan pertambangan batubara yang terdaftar di Bursa Efek Indonesia tahun 2013 - 2017. Pendekatan penelitian yang digunakan dalam penelitian ini adalah pendekatan kuantitatif dengan menggunakan data sekunder. Teknik sampling yang digunakan adalah non probability sampling dengan metode purposive sampling. Jumlah sampel yang digunakan dalam penelitian ini sebanyak 40 sampel. Teknik analisis yang digunakan adalah regresi linear berganda. Berdasarkan hasil penelitian menunjukan bahwa good corporate governance dan ukuran perusahaan berpengaruh pada manajemen laba. Penelitian ini diharapkan mampu memberikan tambahan kajian empiris bagi penelitian selanjutnya yang meneliti tentang manajemen laba dan memberikan kontribusi positif bagi investor dan perusahaan dalam memahami pentingnya penerapan good corporate governance untuk mengurangi tindakan manajemen laba.
\end{abstract}

Kata Kunci: Good corporate governance, ukuran perusahaan, manajemen laba.

\begin{abstract}
The purpose of this study was to determine the effect of good corporate governance and company size on earnings management in coal mining companies listed on the Indonesia Stock Exchange in 2013 - 2017. The research approach used in this study was a quantitative approach using secondary data. The sampling technique used is non probability sampling with a purposive sampling method. The number of samples used in this study were 40 samples. The analysis technique used is multiple linear regression. Based on the results of the study show that good corporate governance and company size influence earnings management. This research is expected to be able to provide additional empirical studies for further research that examines earnings management and makes a positive contribution to investors and companies in understanding the importance of implementing good corporate governance to reduce earnings management actions.

Keywords: Good corporate governance, company size, earnings management.
\end{abstract}

\section{PENDAHULUAN}

Perusahaan yang telah terdaftar di Bursa Efek Indonesia (BEI) memiliki kewajiban untuk menerbitkan laporan keuangan setiap tahunnya. Laporan keuangan merupakan salah satu media dalam penyampaian informasi kepada pihak internal maupun eksternal yang memiliki kepentingan terhadap posisi dan 
kondisi keuangan suatu perusahaan. Laporan keuangan digunakan oleh investor dan kreditor sebagai dasar pertimbangan untuk melakukan investasi maupun memberikan pinjaman. Oleh karena itu, laporan keuangan harus menggambarkan informasi yang sesuai dengan kondisi perusahaan. Salah satu elemen penting dalam laporan keuangan yang digunakan untuk mengukur kinerja manajemen adalah laba.

Informasi mengenai laba mendapat perhatian khusus bagi pihak dalam maupun pihak luar perusahaan untuk mengambil suatu keputusan. Investor akan cenderung lebih tertarik pada perusahaan yang mengalami laba setiap tahunnya. Adanya kecenderungan melihat laba ini diperhatikan oleh pihak manajemen sehingga memungkinkan timbulnya penyimpangan perilaku yang dapat dilakukan pihak manajemen dalam hal menyajikan laporan keuangan.

Informasi laba juga digunakan oleh investor atau pihak lain yang berkepentingan sebagai indikator efisiensi penggunaan dana yang tertanam dalam perusahaan yang diwujudkan dalam tingkat pengembalian dan indikator untuk kenaikan kemakmuran (Agusti, 2013). Laporan keuangan dapat disusun dengan berbagai pilihan metode akuntansi yang digunakan perusahaan sesuai dengan tujuan perusahaan. Menurut Zeptian dan Rohman (2013) prinsip akuntansi telah dibuat dengan sebaik-baiknya, namun prinsip ini memiliki keterbatasan yang dikarenakan fleksibilitas yang diperbolehkannya. Manajemen mempunyai fleksibilitas untuk memilih cara-cara alternatif dalam mencatat transaksi sekaligus opsi-opsi yang ada dalam akuntansi. Fleksibilitas ini dimaksudkan untuk dapat beradaptasi terhadap berbagai situasi ekonomi. 
Akuntansi berbasis akrual dipilih untuk menyusun laporan keuangan karena dapat merefleksikan kondisi keuangan perusahaan secara nyata dan lebih rasional, namun metode ini juga memiliki kelemahan. Menurut Zeptian dan Rohman (2013) mengatakan bahwa akuntansi akrual yang rumit dan rentan atas manipulasi mengakibatkan kekaburan informasi pada laporan keuangan. Kerentanan ini dapat menimbulkan manajemen laba. Menurut Murhadi (2009) manajemen laba terjadi ketika manajer menggunakan pertimbangan dalam menyusun laporan keuangan yang dapat membuat kesalahpahaman pada stakeholders dan shareholders mengenai kondisi keuangan yang ada dalam suatu perusahaan.

Menurut Gunawan et al. (2015) manajemen laba adalah suatu kondisi dimana manajemen melakukan intervensi dalam proses penyusunan laporan keuangan bagi pihak eksternal sehingga dapat meratakan, menaikkan dan menurunkan laba. Menurut Putra et al. (2014) mendefinisikan manajemen laba merupakan pemilihan kebijakan akuntansi oleh manajer dari standar akuntansi yang ada dan secara alamiah dapat memaksimumkan utilitas mereka.

Kepemilikan manajerial akan turut menentukan kebijakan perusahaan serta pengambilan keputusan terhadap penerapan metode akuntansi dalam pengelolaan perusahaan yang tentunya akan memengaruhi manajemen laba dan motivasi manajer perusahaan akan menentukan tindakan manajemen laba (Prabaningrat dan Widanaputra, 2015). Tindakan manajemen laba yang pernah terjadi di Indonesia yakni pada kasus PT. Garda Tujuh Buana Tbk (GTBO). PT Garda 
Tujuh Buana Tbk (GTBO) dituding melakukan pemalsuan laporan keuangan karena ada indikasi kecurangan laporan keuangan perseroan periode 2012.

Per Maret 2013, penjualan PT Garda Tujuh Buana Tbk anjlok 78,75\% menjadi Rp 26,37 miliar dibandingkan penjualan periode tahun sebelumnya yang Rp 124,10 miliar. Beban pokok turun menjadi Rp 40,02 miliar dari beban pokok penjualan sebelumnya Rp 61,85 miliar dan rugi kotor diderita sebesar Rp 13,64 miliar dari laba kotor tahun sebelumnya Rp 62,25 miliar. Pendapatan dari selisih kurs diraih sebesar Rp 2,73 miliar, namun beban umum dan administrasi meningkat menjadi Rp 7,75 miliar. Rugi sebelum pajak diderita Rp 18,67 miliar per maret 2013 dari laba sebelum pajak Rp 58,10 miliar tahun sebelumnya, sedangkan rugi per saham sebesar Rp 7,47 dari laba bersih per saham sebelumnya Rp 23,24. (neraca.co.id)

Kasus lain yang pernah terjadi di sektor pertambangan yaitu kasus PT Timah Persero. Kasus ini terjadi pada tahun 2016, PT Timah (Persero) Tbk diduga memberikan laporan keuangan fiktif pada semester I tahun 2015. Kegiatan laporan keuangan fiktif ini dilakukan guna menutupi kinerja keuangan PT Timah yang terus mengkhawatirkan, kondisi keuangan PT Timah sejak tiga tahun belakangan kurang sehat yang dimulai dari tahun 2013. Ikatan Karyawan Timah (IKT) menilai direksi telah banyak melakukan kebohongan publik melalui media.

Contohnya adalah pada press release laporan keuangan semester I tahun 2015 yang mengatakan bahwa efisiensi dan strategi yang telah telah membuahkan kinerja yang positif. Padahal kenyataanya pada semester I tahun 2015 laba operasi rugi sebesar Rp 59 miliar. Oleh sebab itu, IKT menuntut agar 
jajaran direksi segera mengundurkan diri. Waktu yang diberikan selama hampir dua tahun oleh IKT tidak berhasil dimanfaatkan oleh jajaran direksi untuk membenahi kinerja perseroan. Selain mengalami penurunan laba, PT Timah juga mencatatkan peningkatan utang hampir 100\% dibanding tahun 2013. Pada tahun 2013, utang perseroan hanya mencapai Rp 263 miliar, namun jumlah utang ini meningkat hingga Rp 2,3 triliun pada tahun 2015 (economy.okezone.com).

Dari beberapa kasus di atas, faktor yang menjadi penyebab kecurangan karena manajemen ingin menutupi kondisi perusahaan mereka yang sebenarnya. Hal ini mungkin saja didorong oleh tekanan untuk menunjukkan kinerja yang baik dengan cara memanipulasi informasi yang diberikan kepada pengguna laporan keuangan. Hal lain yang menjadi penyebab terjadinya kasus tersebut adalah karena tata kelola perusahaan di Indonesia yang lemah. Ketika manajemen tidak berhasil dalam mencapai target labanya, sehingga manajemen akan melakukan modifikasi dalam pelaporannya dengan cara memilih dan menerapkan metode akuntansi yang dapat menunjukkan pencapaian laba yang lebih baik agar memperlihatkan kinerja perusahaan yang baik. Teori keagenan menggambarkan bahwa manajemen laba terjadi sebagai akibat dari kepentingan ekonomis yang berbeda antara manajemen selaku agent dan pemilik entitas selaku principal. Perbedaan kepentingan ekonomis ini bisa saja disebabkan atau menyebabkan asimetri informasi antara pemegang saham dan manajemen (Gunawan et al., 2015).

Good Corporate Governance merupakan suatu mekanisme pengawasan terhadap internal perusahaan yang memiliki tujuan menyelaraskan kepentingan 
principal dan agent. Praktik GCG diperlukan untuk mencegah tindakan manajemen laba yang dilakukan oleh manajemen. Penelitian mengenai GCG menghasilkan berbagai mekanisme yang bertujuan untuk meyakinkan bahwa tindakan manajemen selaras dengan kepentingan pemegang saham. Ada beberapa mekanisme GCG yang sering digunakan dalam penelitian untuk mengetahui pengaruhnya terhadap manajemen laba, diantaranya adalah konsentrasi kepemilikan, proporsi dewan komisaris dan komite audit (Wahyono, 2012). Penelitian ini memfokuskan pada pengaruh penerapan Good Corporate Governance yang dilihat dari kepemilikan manajerial, dewan komisaris, komite audit, dan ukuran perusahaan terhadap praktik manajemen laba pada perusahaan pertambangan batubara yang terdaftar di BEI.

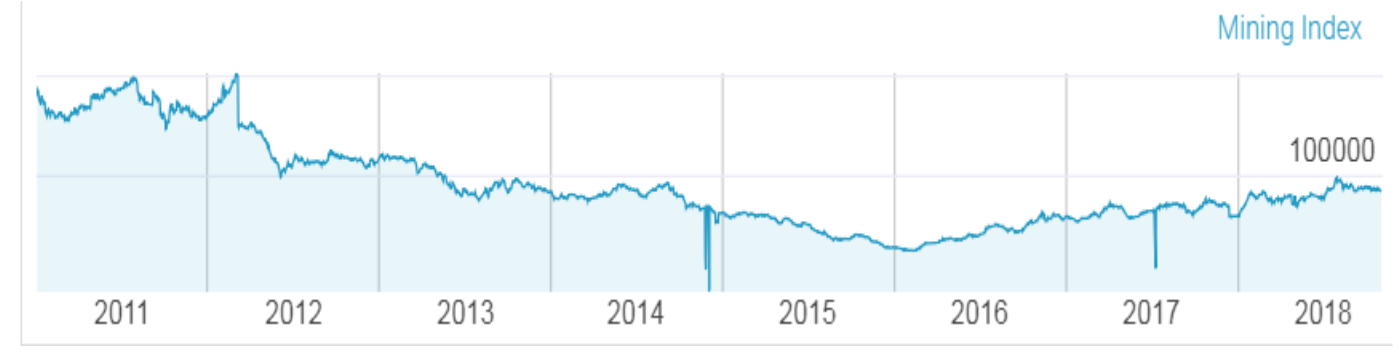

Gambar 1. Indeks perusahaan pertambangan batubara

Sumber : indonesia-investment.com, 2018

Dari grafik tersebut dapat dilihat bahwa indeks sektor pertambangan mengalami fluktuasi dari tahun 2011-2018. Tahun 2012 menempati posisi tertinggi dan posisi terendah terjadi pada tahun 2015-2016.

Penelitian terdahulu mengenai manajemen laba telah banyak dilakukan, diantaranya penelitian yang dilakukan oleh Zeptian dan Rohman (2013), Guna dan Herawaty (2010) menunjukan bahwa komite audit berpengaruh positif namun tidak signifikan terhadap manajemen laba. Hasil yang berbeda dikemukakan oleh 
Octavianto dan Widagdo (2014), Chtourou et al. (2001) menemukan bahwa proporsi komite audit berpengaruh negatif terhadap manajemen laba.

Penelitian yang dilakukan oleh Guna dan Herawaty (2010) menyatakan dewan komisaris berpengaruh positif namun tidak signifikan terhadap manajemen laba. Octavianto dan Widagdo (2014) meneliti pengaruh praktik Good Corporate Governance terhadap manajemen laba, menunjukkan bahwa proporsi dewan komisaris terbukti berpengaruh positif terhadap manajemen laba yang dilakukan oleh perusahaan. Berbeda dengan penelitian Zeptian dan Rohman (2013) menyatakan bahwa dewan komisaris berpengaruh negatif terhadap manajemen laba

Penelitian yang dilakukan oleh Zeptian dan Rohman (2013) menunjukan bahwa ukuran perusahaan berpengaruh positif terhadap manajemen laba. Berbeda dengan penelitian yang dilakukan oleh Gunawan et al. (2015), Guna dan Herawaty (2010), Kusumawardhani (2012) yang menyatakan ukuran perusahaan berpengaruh negatif dan tidak signifikan terhadap manajemen laba. Hal ini disebabkan semakin besar ukuran perusahaan maka semakin dipandang kritis oleh pemegang saham, sehingga manajer memilih untuk tidak melakukan manipulasi laporan keuangannya

Berdasarkan fenomena diatas, kasus manajemen laba masih banyak terjadi dan menarik untuk diteliti ulang serta adanya inkonsistensi hasil yang terjadi pada penelitian-penelitian terdahulu. Sektor yang dipilih pada penelitian ini adalah perusahaan pertambangan batubara merupakan sektor usaha yang cukup besar 
apabila dibandingkan dengan sektor lain, sehingga membuat sektor pertambangan batubara menjadi sektor yang diminati investor.

Berdasarkan latar belakang yang telah diuraikan, maka peneliti ingin meneliti Pengaruh Good Corporate Governance dan Ukuran Perusahaan pada Manajemen Laba (Studi pada perusahaan pertambangan batubara yang terdaftar di Bursa Efek Indonesia tahun 2013-2017).

Pengaruh penerapan $G C G$ dalam penelitian ini dilihat dari kepemilikan manajerial, dewan komisaris, komite audit. Praktik manajemen laba sangat ditentukan oleh motivasi manajer perusahaan. Teori keagenan menyatakan terdapat perbedaan kepentingan antara agent dan principal, untuk menyelaraskan perbedaan kepentingan tersebut maka manajemen diberikan kepemilikian saham perusahaan untuk meminimalisir tindakan manajemen laba karena manajemen berperan sebagai agent sekaligus principal. Motivasi yang berbeda akan menghasilkan besaran manajemen laba yang berbeda. Dua hal tersebut akan mempengaruhi manajemen laba, sebab kepemilikan manajerial ikut menentukan kebijakan dan pengambilan keputusan terhadap metode akuntansi yang diterapkan pada perusahaan yang kelolanya. Octavianto dan Widagdo (2014) menjelaskan bahwa persentase tertentu kepemilikan saham oleh pihak manajemen cenderung mempengaruhi tindakan manajemen laba. Penelitian ini menjelaskan bahwa semakin tinggi struktur kepemilikan manajerial diharapkan pihak manajemen akan berusaha semaksimal mungkin untuk kepentingan para pemegang saham.

Penelitian Arthawan dan Wirasedana (2018) menyatakan bahwa kepemilikan manajerial berpengaruh negatif signifikan terhadap manajemen laba. 
Jadi semakin besar saham yang dimiliki oleh manajer dimungkinkan tindakan manajer yang melakukan manajemen laba akan berkurang karena manajer merasa ikut mempunyai perusahaan. Midiastuty dan Mahfoedz (2003) menyatakan bahwa kepemilikan manajerial dengan manajemen laba berhubungan negatif. Penelitian yang dilakukan oleh Ujiyantho dan Pramuka (2007) menemukan hasil adanya pengaruh kepemilikan manajerial terhadap tindakan manajemen laba.

Farida et al. (2010) menyatakan bahwa kepemilikan manajerial berpengaruh negatif terhadap manajemen laba, artinya semakin besar kepemilikan saham oleh pihak manajemen dapat mengurangi tindakan manajemen laba dalam suatu perusahaan. Dengan adanya kepemilikan manajerial yang tinggi maka manajemen akan mengoptimalkan kinerja mereka dan memperhatikan kesejahteraan para pemegang saham maka tindakan manajemen laba dapat berkurang. Berdasarkan kajian teoritis dan empiris tersebut, maka hipotesis yang diajukan yaitu:

$\mathrm{H}_{1}$ : Kepemilikan manajerial berpengaruh negatif pada manajemen laba.

Dewan komisaris adalah sebuah dewan yang bertugas untuk melakukan pengawasan dan memberikan nasihat kepada manajemen perusahaan. Melalui perannya dalam menjalankan fungsi pengawasan, dewan komisaris dapat mempengaruhi pihak manajemen dalam menyusun laporan keuangan sehingga diperoleh suatu laporan laba yang berkualitas. Berdasarkan teori keagenan, dewan komisaris dianggap sebagai mekanisme pengendalian intern tertinggi, yang bertanggung jawab untuk memonitor tindakan manajemen puncak (Prastiti dan Meiranto, 2013). Pengawasan dilakukan agar kecenderungan manajer untuk 
melakukan manajemen laba berkurang agar investor tetap memberikan kepercayaan untuk menanamkan investasinya pada perusahaan.

Rafdan Anggana dan Prastiwi (2013), Prastiti dan Meiranto (2013), Prabaningrat dan Widanaputra (2015) meneliti mengenai good corporate governance terhadap manajemen laba, menunjukan bahwa dewan komisaris berpengaruh negatif pada manajemen laba. Semakin banyak jumlah anggota dewan komisaris maka pengawasan terhadap laporan keuangan akan lebih ketat dan objektif, sehingga kecurangan yang dilakukan oleh manajer untuk memanipulasi laba dapat diminimalisir dan manajemen laba dapat dihindari. Dengan jumlah dewan komisaris yang banyak maka akan mampu memudahkan dalam dalam melakukan pengawasan kepada manajemen sehingga tindakan manajemen laba dapat berkurang. Berdasarkan kajian teoritis dan empiris tersebut, maka hipotesis yang diajukan yaitu:

$\mathrm{H}_{2}$ : Dewan komisaris berpengaruh negatif pada manajemen laba.

Komite audit dibentuk oleh dewan komisaris untuk melakukan tugas pengawasan pengelolaan perusahaan. Keberadaan komite audit sangat penting bagi pengelolaan perusahaan karena merupakan salah satu sistem pengendalian dalam perusahaan yang menghubungkan antara pemegang saham dan dewan komisaris dengan pihak manajemen. Komite audit bertugas melakukan pengawasan untuk meningkatkan efektivitas dalam menciptakan keterbukaan dan pelaporan keuangan yang berkualitas, ketaatan terhadap peraturan perundangundangan yang berlaku, dan pengawasan internal yang memadai (Sulistyanto, 2008). 
Komite audit memiliki tanggung jawab pengawasan untuk proses pelaporan keuangan perusahaan dan tujuan utamanya adalah untuk meningkatkan kredibilitas laporan keuangan yang diaudit. Dalam kapasitas ini, komite audit bertindak sebagai perantara antara manajemen dan auditor eksternal (Rafdan Anggana dan Prastiwi, 2013). Semakin besar komposisi komite audit maka pemeriksaan ketaatan terhadap peraturan internal perusahaan dan laporan keuangan auditan akan lebih maksimal sehingga kemungkinan asimetri informasi baik itu berupa moral hazard maupun adverse selection antara manajer dan pemegang saham akan dapat diminimalisir dan praktik manajemen laba dapat dihindari.

Menurut Octavianto dan Widagdo (2014) terdapat hubungan antara keahlian komite audit di bidang keuangan dan manajemen laba dengan hasil penelitian bahwa keahlian komite audit di bidang keuangan terbukti efektif mengurangi manajemen laba. Semakin banyaknya anggota komite audit akan meningkatkan kinerja komite audit tersebut. Hal ini dapat membuat fungsi pengawasan semakin meningkat, sehingga kualitas pelaporan yang dilakukan oleh manajemen terjamin.

Penelitian menurut Chtourou et al. (2001), (Lidiawati dan Asyik, 2016), (Rafdan Anggana dan Prastiwi, 2013) menemukan bahwa komite audit berpengaruh negatif terhadap manajemen laba. Artinya, semakin banyak anggota komite audit maka semakin kecil tindakan manajemen laba yang dilakukan oleh perusahaan. Dengan banyaknya jumlah komite audit maka akan mampu meningkatkan fungsi pengawasan dan meningkatkan kualitas laporan keuangan 
sehingga tindakan manajemen laba semakin kecil. Berdasarkan kajian teoritis dan empiris tersebut, maka hipotesis yang diajukan yaitu:

$\mathrm{H}_{3}$ : Komite audit berpengaruh negatif terhadap manajemen laba.

Menurut Putra et al. (2014) menemukan bukti bahwa perusahaanperusahaan yang lebih besar memiliki dorongan yang lebih besar pula untuk melakukan manajemen laba dibandingkan dengan perusahaan-perusahaan yang lebih kecil karena perusahaan-perusahaan yang lebih besar menjadi subyek pemeriksaan pengawasan yang lebih ketat dari pemerintah dan masyarakat. Ukuran perusahaan pada umumnya diproksikan dengan nilai total aset, total penjualan dan kapitalisasi pasar. Dari ketiga variabel tersebut, nilai total aset relatif lebih stabil dibandingkan dengan nilai penjualan dan kapitalisasi pasar dalam mengukur ukuran perusahaan (Putra et al., 2014).

Agusti dan Pramesti (2013) mengatakan bahwa besaran perusahaan / skala perusahaan adalah ukuran perusahaan yang di tentukan dari jumlah total aset yang dimiliki perusahaan. Penelitian Defond (1993) menemukan bahwa ukuran perusahaan berkorelasi secara positif dengan manajemen laba. Perusahan besar mempunyai insentif yang cukup besar untuk melakukan manajemen laba, karena salah satu alasan utamanya adalah perusahaan besar harus mampu memenuhi ekspektasi dari investor atau pemegang sahamnya. Selain itu, semakin besar perusahaan, semakin banyak estimasi dan penilaian yang perlu diterapkan untuk tiap jenis aktivitas perusahaan yang semakin banyak (Agusti dan Pramesti, 2013).

Penelitian yang dilakukan Fanani (2014) menemukan bahwa ukuran perusahaan memiliki korelasi negatif terhadap manajemen laba. Penelitian 
tersebut mengatakan bahwa perusahaan yang besar akan mempunyai pengungkapan pelaporan keuangaan yang lebih lengkap dan auditor yang berkualitas dibandingkan perusahaan yang lebih kecil. Hasil yang berbeda diperoleh dari penelitian yang dilakukan oleh Guna dan Herawaty (2010), Radzi et al. (2011) dan Watiningsih (2011) menunjukkan bahwa ukuran perusahaan berpengaruh positif terhadap manajemen laba. Artinya semakin besar ukuran suatu perusahaan yang diproksikan dalam total aset akan meningkatkan praktik manajemen laba. Semakin besar ukuran perusahaan maka perusahaan tersebut mempunyai laporan keuangan yang lebih lengkap, handal dan auditor yang berkualitas dibanding ukuran perusahaan yang lebih kecil sehingga tindakan manajemen laba semakin kecil. Berdasarkan kajian teoritis dan empiris tersebut, maka hipotesis yang diajukan yaitu:

$\mathrm{H}_{4}$ : Ukuran perusahaan berpengaruh negatif terhadap manajemen laba.

\section{METODE PENELITIAN}

Lokasi penelitian ini adalah perusahaan sektor pertambangan batubara yang terdaftar di Bursa Efek Indonesia (BEI) tahun 2013-2017. Objek penelitian pada penelitian ini adalah praktik manajemen laba pada perusahaan sektor pertambangan batubara yang terdaftar di BEI periode tahun 2013-2017.

Populasi dalam penelitian ini adalah seluruh perusahaan pertambangan batubara yang terdaftar di BEI periode 2013-2017 yang berjumlah 22 perusahaan. Sampel yang digunakan dalam penelitian ini adalah sebanyak 8 perusahaan 
pertambangan batubara yang terdaftar di BEI periode 2013-2017 yang dipilih melalui teknik purposive sampling.

Uji hipotesis dalam penelitian ini menggunakan analisis regresi linear berganda, analisis regresi linear berganda digunakan untuk meneliti pengaruh variabel bebas terhadap variabel terikat serta menunjukkan arah hubungan variabel-variabel tersebut. Berdasarkan pembahasan teori, data penelitian, variabel-variabel penelitian, dan penelitian terdahulu maka bentuk persamaan regresi linear berganda penelitian ini adalah sebagai berikut.

$\mathrm{Y}=\mathrm{a}+\beta_{1} \mathrm{KM}+\beta_{2} \mathrm{DK}+\beta_{3} \mathrm{KA}+\beta_{4} \mathrm{UP}+\mathrm{e}$

$\mathrm{Y} \quad=$ Manajemen Laba

a $\quad=$ Konstanta

$\beta \quad=$ Koefisien regresi

$\mathrm{KM}=$ Kepemilikan Manajerial

DK = Dewan Komisaris

KA $=$ Komite Audit

UP $=$ Ukuran Perusahaan

e $\quad=$ error

\section{HASIL DAN PEMBAHASAN}

Nilai minimum kepemilikan manajerial adalah 0 yang terdapat pada PT Baramulti Suksessarana Tbk, PT Golden Energy Mines Tbk, PT Samindo Resources Tbk, PT Bukit Asam Tbk, PT Toba Bara Sejahtra Tbk pada tahun 2013-2017 dan nilai maksimumnya adalah 1 yang terdapat pada PT Adaro Energy Tbk, Indo Tambangraya Megah Tbk, PT Resource Alam Indonesia Tbk pada tahun 20132017. Nilai rata-rata untuk kepemilikan manajerial adalah 0,38 hal ini berarti ratarata kepemilikan manajerial pada sampel amatan dalam penelitian ini berjumlah 0,38. Standar deviasi untuk kepemilikan manajerial adalah 0,490 yang memiliki 
arti terjadi penyimpangan nilai kepemilikan manajerial pada nilai rata-ratanya sebesar 0,490 .

Tabel 1.

Hasil Analisis Statistik Deskriptif

\begin{tabular}{lrrrrr}
\hline & N & Minimum & Maximum & Mean & $\begin{array}{c}\text { Std. } \\
\text { Deviation }\end{array}$ \\
\hline KM & 40 & 0 & 1 & 0.38 & 0.490 \\
DK & 40 & 3 & 9 & 5.50 & 1.1313 \\
KA & 40 & 2 & 4 & 3.06 & 0.316 \\
UP & 40 & 27.70 & 32.10 & 29.4933 & 1.29042 \\
Manajemen Laba & 40 & -1.05 & 1.08 & 0.1313 & 0.45487 \\
Valid N (listwise) & 40 & & & & \\
\hline Sumber: Data diolah, 2018 & & & & &
\end{tabular}

Sumber: Data diolah, 2018

Nilai minimum dewan komisaris adalah 3 yang terdapat pada PT Samindo Resources Tbk tahun 2015 -2017, PT Toba Bara Sejahtra Tbk tahun 2015-2016 dan nilai maksimumnya adalah 9 yang terdapat pada PT Baramulti Suksessarana Tbk tahun 2016. Nilai rata-rata untuk dewan komisaris adalah 5,50 hal ini berarti rata - rata dewan komisaris pada sampel amatan dalam penelitian ini berjumlah 5,50. Standar deviasi untuk dewan komisaris adalah 1,1313 yang memiliki arti terjadi penyimpangan nilai dewan komisaris pada nilai rata-ratanya sebesar 1,1313 .

Nilai minimum komite audit adalah 2 yang terdapat pada PT Baramulti Suksessarana Tbk tahun 2014 dan nilai maksimumnya adalah 4 yang terdapat pada PT Bukit Asam Tbk tahun 2013-2015. Nilai rata-rata untuk komite audit adalah 3,06 hal ini berarti rata - rata komite audit pada sampel amatan dalam penelitian ini berjumlah 3,06. Standar deviasi untuk komite audit adalah 0,316 yang memiliki arti terjadi penyimpangan nilai komite audit pada nilai rata-ratanya sebesar 0,316 . 
Nilai minimum ukuran perusahaan adalah 27,70 yang terdapat pada PT Resource Alam Indonesia Tbk tahun 2013-2014 dan nilai maksimumnya adalah 32,10 yang terdapat pada PT Adaro Energy Tbk tahun 2017. Nilai rata-rata untuk ukuran perusahaan adalah 29,4933 hal ini berarti rata - rata ukuran perusahaan pada sampel amatan dalam penelitian ini berjumlah 29,4933. Standar deviasi untuk ukuran perusahaan adalah 1,29042 yang memiliki arti terjadi penyimpangan nilai ukuran perusahaan pada nilai rata-ratanya sebesar 1,29042.

Nilai minimum manajemen laba adalah $-1,05$ yang terdapat pada PT Resource Alam Indonesia Tbk tahun 2014 dan nilai maksimumnya adalah 1,08 yang terdapat pada PT Baramulti Suksessarana Tbk tahun 2017. Nilai rata-rata untuk manajemen laba adalah 0,1313 hal ini berarti rata-rata manajemen laba pada sampel amatan dalam penelitian ini berjumlah 0,1313. Standar deviasi untuk manajemen laba adalah 0,45487 yang memiliki arti terjadi penyimpangan nilai manajemen laba pada nilai rata-ratanya sebesar 0,45487 .

\section{Tabel 2.}

Hasil Uji Analisis Regresi Linear Berganda

\begin{tabular}{|c|c|c|c|c|c|}
\hline \multirow[t]{2}{*}{ Model } & \multicolumn{2}{|c|}{$\begin{array}{l}\text { Unstandardized } \\
\text { Coefficients }\end{array}$} & \multirow{2}{*}{$\begin{array}{c}\text { Standardized } \\
\text { Coefficients } \\
\text { Beta } \\
\end{array}$} & \multirow[b]{2}{*}{$\mathrm{t}$} & \multirow[b]{2}{*}{ Sig. } \\
\hline & $\mathrm{B}$ & Std. Error & & & \\
\hline 1 (Constant) & -3.157 & 1.337 & & -2.361 & 0.024 \\
\hline Kepemilikan Manajerial & -0.624 & 0.125 & -0.672 & -5.005 & 0.000 \\
\hline Dewan Komisaris & 0.126 & 0.040 & 0.363 & 3.134 & 0.003 \\
\hline Komite Audit & -0.527 & 0.177 & -0.366 & -2.982 & 0.005 \\
\hline Ukuran Perusahaan & 0.151 & 0.048 & 0.427 & 3.133 & 0.003 \\
\hline R Square & & & & & 0.553 \\
\hline Adjusted R Square & & & & & 0.480 \\
\hline F Statistik & & & & & 10.006 \\
\hline Signifikansi & & & & & 0.000 \\
\hline
\end{tabular}

$$
\mathrm{Y}=-3.157-0.624 \mathrm{KM}+0.126 \mathrm{DK}-0.527 \mathrm{KA}+0.151 \mathrm{UP}
$$

Berdasarkan persamaan tersebut, dapat dijelaskan hal-hal sebagai berikut: 
Nilai konstanta -3.157 menunjukan bahwa bila good corporate governance dan ukuran perusahaan sama dengan nol, maka manajemen laba akan menurun sebesar -3.157 satuan.

Nilai koefisien regresi kepemilikan manajerial sebesar -0.624 menunjukan bahwa bila kepemilikan manajerial naik satu satuan, maka manajemen laba akan mengalami penurunan sebesar -0.624 satuan dengan asumsi variabel lainnya konstan.

Nilai koefisien regresi dewan komisaris sebesar 0.126 menunjukan bahwa bila dewan komisaris naik satu satuan, maka manajemen laba akan mengalami peningkatan sebesar 0.126 satuan dengan asumsi variabel lainnya konstan.

Nilai koefisien regresi komite audit sebesar -0.527 menunjukan bahwa bila komite audit naik satu satuan, maka manajemen laba akan mengalami penurunan sebesar -0.527 satuan dengan asumsi variabel lainnya konstan.

Nilai koefisien regresi ukuran perusahaan sebesar 0.151 menunjukan bahwa bila ukuran perusahaan naik satu satuan, maka manajemen laba akan mengalami peningkatan sebesar 0.151 satuan dengan asumsi variabel lainnya konstan.

Uji koefisien determinasi digunakan untuk mengukur seberapa jauh kemampuan model dalam menerangkan variasi variabel independen terhadap variabel dependen. Hasil dari koefisien determinasi dapat dilihat pada tabel 2.

Berdasarkan Tabel 2 dapat diketahui bahwa Adjusted R Square sebesar 0.480. Hal ini berarti bahwa $48 \%$ variabel manajemen laba (discretionary accruals) dapat dijelaskan oleh variabel bebas yaitu good corporate governance 
dan ukuran perusahaan. Sisanya sebesar $52 \%$ dijelaskan oleh faktor-faktor lain yang tidak dijelaskan dalam model penelitian.

Uji F digunakan untuk menguji signifikansi secara serempak seluruh variabel bebas terhadap variabel terikat. Uji $\mathrm{F}$ dilakukan dengan melihat nilai signifikansi pada tabel ANOVA.

Tabel 3.

Hasil Uji Kelayakan Model (Uji F)

\begin{tabular}{llrrrrr}
\hline Model & & Sum of Squares & Df & Mean Square & F & Sig. \\
\hline 1 & Regression & 4.305 & 4 & 1.076 & 10.006 & $0.000^{\mathrm{a}}$ \\
& Residual & 3.765 & 35 & 0.108 & & \\
& Total & 8.069 & 39 & & & \\
\hline
\end{tabular}

Sumber: Data diolah, 2018

Berdasarkan Tabel 3 dapat diketahui bahwa model persamaan ini memiliki tingkat signifikansi, yaitu 0.000 lebih kecil dibandingkan taraf signifikansi $(\alpha=$ 0,05) maka dapat disimpulkan bahwa variabel bebas dalam model penelitian ini secara simultan dapat berpengaruh terhadap variabel terikat yaitu manajemen laba.

Hasil pengujian dengan menggunakan regresi linear berganda, diperoleh nilai signifikansi sebesar 0,000 dengan nilai koefisien regresi sebesar -0,624. Hasil pengujian regresi linear berganda mendukung arah hipotesis yang telah dirumuskan, sehingga hipotesis penelitian diterima. Hasil ini mempunyai arti bahwa kepemilikan manajerial berpengaruh negatif dan signifikan pada manajemen laba.

Hasil hipotesis ini mendukung penelitian yang dilakukan oleh Octavianto dan Widagdo (2014), Arthawan dan Wirasedana (2018), Farida et al. (2010) yang menyatakan bahwa kepemilikan manajerial berpengaruh negatif terhadap manajemen laba, artinya semakin besar kepemilikan saham oleh pihak manajemen 
dapat mengurangi tindakan manajemen laba dalam suatu perusahaan. Dalam teori keagenan menjelaskan tentang hubungan antara agent dengan principal, dimana agent harus bertanggungjawab dan memperhatikan kesejahteraan principal. Dalam teori ini terdapat perbedaan kepentingan antara agent dan principal, dimana agent berfokus pada tujuan yang menguntungkan dirinya sendiri sedangkan principal berfokus pada peningkatan laba di setiap pembagian deviden.

Pada banyak kasus yang terjadi manajemen sering memberikan informasi yang merugikan prinsipal yang tujuannya untuk memberikan gambaran kondisi maupun kinerja perusahaan yang baik, untuk mengatasi hal tersebut maka manajemen diberikan kesempatan untuk memiliki saham perusahaannya bertujuan agar manajemen mampu mengoptimalkan kinerja mereka untuk mencapai target yang harus mereka penuhi seusai dengan keputusan dalam RUPS. Dengan manajemen memiliki saham dari perusahaannya maka tindakan manajemen laba akan berkurang karena apabila mereka melakukan hal tersebut maka akan merugikan diri mereka yang menjadi agent sekaligus principal. Tentu hal tersebut akan berdampak buruk bagi perusahaan.

Hasil pengujian dengan menggunakan regresi linear berganda, diperoleh nilai signifikansi sebesar 0,003 dengan nilai koefisien regresi sebesar 0,126. Hasil pengujian regresi linear berganda tidak mampu mendukung arah hipotesis yang telah dirumuskan, sehingga hipotesis penelitian tidak diterima. Hasil ini mempunyai arti bahwa dewan komisaris berpengaruh positif dan signifikan pada manajemen laba.

Hasil penelitian ini tidak didukung dengan penelitian yang dilakukan oleh Rafdan Anggana dan Prastiwi (2013), Prastiti dan Meiranto (2013), Prabaningrat 
dan Widanaputra (2015) yang menunjukkan bahwa dewan komisaris terbukti berpengaruh negatif terhadap manajemen laba yang dilakukan oleh perusahaan. Hasil penelitian ini didukung oleh penelitian Firnanti (2017), Bangun dan Vincent (2008), Octavianto dan Widagdo (2014) yang menyatakan bahwa dewan komisaris berpengaruh positif pada manajemen laba. Jumlah dewan komisaris yang sedikit maka akan mampu memudahkan dalam melakukan koordinasi dan pengawasan kepada manajemen sehingga tindakan manajemen laba dapat berkurang.

Berdasarkan teori keagenan, dewan komisaris dianggap sebagai mekanisme pengendalian intern tertinggi, yang bertanggung jawab untuk memonitor tindakan manajemen. Pengawasan dilakukan agar kecenderungan manajemen untuk melakukan manajemen laba berkurang agar investor tetap memberikan kepercayaan untuk menanamkan investasinya pada perusahaan tersebut. Dengan jumlah dewan komisaris yang sedikit maka akan mampu memudahkan dalam melakukan pengawasan kepada manajemen sehingga dapat mengurangi manajemen laba.

Hasil pengujian dengan menggunakan regresi linear berganda, diperoleh nilai signifikansi sebesar 0,005 dengan nilai koefisien regresi sebesar -0,527. Hasil pengujian regresi linear berganda mendukung arah hipotesis yang telah dirumuskan, sehingga hipotesis penelitian diterima. Hasil ini mempunyai arti bahwa komite audit berpengaruh negatif dan signifikan pada manajemen laba.

Hasil penelitian menurut Chtourou et al. (2001), Lidiawati (2016), Octavianto dan Widagdo (2014) menemukan bahwa komite audit berpengaruh 
negatif pada manajemen laba. Artinya, semakin banyak anggota komite audit maka semakin kecil tindakan manajemen laba yang dilakukan oleh manajemen. Keberadaan komite audit bermanfaat dalam mengatasi konflik kepentingan yang terjadi dalam teori keagenan yang tujuannya untuk menjamin transparansi, keterbukaan laporan keuangan, keadilan bagi stakeholder, dan pengungkapan informasi yang dilakukan oleh manajemen sehingga tindakan manajemen laba dapat diminimalisir.

Semakin tinggi tingkat pengawasan komite audit maka semakin rendah kemungkinan manajemen untuk melakukan manajemen laba pada laporan keuangan. Kondisi ini mencerminkan keefektifan komite audit dalam kaitannya pelaksanaan tanggungjawabnya sebagai pengawas kualitas laporan keuangan untuk memberi batasan terjadinya praktik manajemen laba di dalam perusahaan. Jumlah anggota komite audit yang semakin banyak maka proses mekanisme pengawasan yang dijalankan komite audit akan semakin berkualitas pula. Pihak komite audit yang ada di dalam perusahaan tentunya akan lebih menuntut prinsip transparansi dalam kaitannya dengan pelaporan keuangan perusahaan yang bertujuan menyajikan informasi yang sesungguhnya sehingga tidakan manajemen laba akan semakin berkurang.

Hasil pengujian dengan menggunakan regresi linear berganda, diperoleh nilai signifikansi sebesar 0,003 dengan nilai koefisien regresi sebesar 0,151 . Hasil pengujian regresi berganda tidak mampu mendukung arah hipotesis yang telah dirumuskan, sehingga hipotesis penelitian tidak diterima. Hasil ini mempunyai arti 
bahwa ukuran perusahaan berpengaruh positif dan signifikan pada manajemen laba.

Hasil penelitian ini tidak konsisten dengan penelitian yang dilakukan oleh Fanani (2014) yang menemukan bahwa ukuran perusahaan memiliki korelasi negatif terhadap manajemen laba. Hasil penelitian ini konsisten dengan penelitian yang dilakukan oleh Guna dan Herawaty (2010), Radzi et al. (2011) dan Watiningsih (2011) menunjukkan bahwa ukuran perusahaan berpengaruh positif terhadap manajemen laba. Artinya semakin besar ukuran suatu perusahaan yang diproksikan dalam total aset akan meningkatkan praktik manajemen laba.

Hal ini disebabkan karena perusahaan yang besar memiliki dorongan yang lebih besar pula untuk melakukan manajemen laba dibandingkan dengan perusahaan -perusahaan yang lebih kecil karena perusahaan-perusahaan yang besar harus mampu memenuhi ekspektasi dari investor atau pemegang sahamnya. Investor pada umumnya menginginkan kinerja dan kondisi perusahaan yang selalu dalam kondisi baik, sehingga apabila perusahaan mengalami suatu masalah dalam kinerja keuangan maka akan muncul tindakan manajemen untuk melakukan manajemen laba yang tujuannya untuk menciptakan suatu kondisi atau kinerja yang selalu baik di mata investor.

Penelitian ini dapat memberikan kontribusi mengenai pengaruh good corporate governance dan ukuran perusahaan pada manajemen laba di perusahaan pertambangan batubara yang terdaftar di BEI periode 2013-2017. Hasil pengujian regresi linear berganda menemukan bahwa seluruh variabel bebas berpengaruh 
pada manajemen laba sehingga hasil penelitian ini mampu membuktikan secara empiris teori keagenan.

Penelitian ini dapat memberikan kontribusi positif bagi semua pihak khususnya pihak investor dan perusahaan. Bagi pihak perusahaan hendaknya bersungguh-sungguh dalam penerapan dari Good Corporate Governance (GCG). Dengan adanya kepemilikan manajerial dan pengawasan yang ketat dari dewan komisaris maupun komite audit maka tindakan manajemen laba akan berkurang. Tindakan manajemen laba akan berdampak negatif kepada investor karena merasa dirugikan atas informasi yang tidak sesuai dengan kinerja perusahaan, tentu investor akan enggan berinvestasi di perusahaan tersebut dan citra perusahaan akan menurun.

Bagi pihak investor dalam berinvestasi harus memperhatikan implementasi good corporate governance ini karena GCG diciptakan untuk mengatasi konflik kepentingan antara agent dan principal dan bertujuan untuk mensejahterakan para investor. Dengan memilih perusahaan yang telah menerapkan GCG dengan sungguh-sungguh bukan hanya untuk formalitas memenuhi aturan yang telah ditetapkan baik disegala ukuran perusahaan maka kesejahteraan investor akan sangat diperhatikan karena agent bertanggungjawab penuh kepada principal.

\section{SIMPULAN}

Hasil pengujian regresi linear berganda menunjukkan bahwa kepemilikan manajerial berpengaruh negatif dan signifikan pada manajemen laba. Ini 
mengindikasikan bahwa apabila manajemen perusahaan memiliki saham perusahaannya maka manajemen akan mengoptimalkan kinerja mereka dan memperhatikan kesejahteraan para investor. Oleh karena itu dengan adanya kepemilikan manajerial maka tindakan manajemen laba akan berkurang.

Hasil pengujian regresi linear berganda menunjukkan bahwa dewan komisaris berpengaruh positif dan signifikan pada manajemen laba. Ini mengindikasikan bahwa dengan jumlah dewan komisaris yang sedikit maka akan mampu memudahkan dalam hal pengawasan kepada manajemen sehingga dapat mengurangi tindakan manajemen laba.

Hasil pengujian regresi linear berganda menunjukkan bahwa komite audit berpengaruh negatif dan signifikan pada manajemen laba. Ini mengindikasikan bahwa dengan jumlah komite audit yang banyak maka proses mekanisme pengawasan yang dijalankan komite audit akan semakin berkualitas pula. Semakin tinggi tingkat pengawasan komite audit maka semakin rendah kemungkinan manajemen untuk melakukan manajemen laba pada laporan keuangan.

Hasil pengujian regresi linear berganda menunjukkan bahwa ukuran berpengaruh positif dan signifikan pada manajemen laba. Ini mengindikasikan bahwa perusahaan besar memiliki dorongan yang lebih besar pula untuk melakukan manajemen laba dibandingkan dengan perusahaan kecil karena perusahaan besar harus mampu memenuhi ekspektasi dari investor. Investor pada umumnya menginginkan kinerja dan kondisi perusahaan yang selalu dalam kondisi baik, sehingga apabila perusahaan mengalami suatu masalah dalam kinerja keuangan maka akan muncul tindakan manajemen untuk melakukan 
manajemen laba yang tujuannya untuk menciptakan suatu kondisi atau kinerja yang baik dimata investor

Bagi pihak manajemen perusahaan disarankan untuk meningkatkan kualitas implementasi dari GCG sehingga nantinya akan mampu memberikan kontribusi yang positif dan bermanfaat bagi para investor. Bukan hanya memenuhi aturan yang telah ditetapkan. Dengan mengimplementasikan GCG disegala ukuran perusahaan yang ada di BEI khususnya pertambangan batubara maka akan mampu memberikan kinerja dan kondisi keuangan perusahaan yang baik, para investor akan tertarik dengan penyampaian informasi yang lengkap dan transparan. Hal tersebut tentu akan mempengaruhi keberlangsungan perusahaan nantinya.

Sebelum melakukan suatu investasi kedalam sebuah perusahaan sebaiknya para calon investor lebih mempertimbangkan kondisi keuangan perusahaan, penerapan GCG dalam perusahaan, kinerja perusahaan, dan faktor-faktor lainnya yang bisa memberikan gambaran informasi mengenai kondisi sebenarnya dari perusahaan tersebut. Perusahaan yang telah mengimplementasikan GCG dengan sungguh-sungguh maka kesejahteraan dari para investor sangat diperhatikan, tindakan seperti manajemen laba yang berdampak merugikan para investor akan berkurang karena hal tersebut bukan hanya merugikan investor tetapi citra perusahaan tersebut sehingga investor akan enggan berinvestasi di perusahaan tersebut.

Penelitian selanjutnya diharapkan dapat memperluas ruang lingkup penelitian, tidak hanya pada perusahaan pertambangan batubara namun juga pada 
perusahaan yang bergerak di sektor lain. Selain itu peneliti juga dapat menambah periode pengamatan dan menggunakan variabel - variabel lain yang berpengaruh pada manajemen laba.

\section{REFERENSI}

Agusti, R., dan Pramesti, T. (2013). Pengaruh Asimetri Informasi, Ukuran Perusahaan, Kepemilikan Manajerial Terhadap Manajemen Laba. Jurnal Ekonomi, 17(1), 54-65.

Arthawan, P. T., dan Wirasedana, I. W. P. (2018). Pengaruh Kepemilikan Manajerial, Kebijakan Utang dan Ukuran Perusahaan Terhadap Manajemen Laba, 22, 1-29.

Bangun, Nurainun dan Vincent. (2008). Analisis Hubungan Komponen Good Corporate Governance Terhadap Manajemen Laba Dengan Kinerja Keuangan Pada Perusahaan Manufaktur Yang Terdaftar di Bursa Efek Indonesia. Jurnal Akuntansi, Tahun XII (3): 53-68.

Chtourou, S.M., \& L. Courteau. (2001). Earnings Management and Corporate Governance.

Fanani, Z. (2014). Karakteristik Perusahaan Dan Corporate Governance Terhadap Manajemen Laba: Studi Analisis Meta. Jurnal Keuangan Dan Perbankan, 18(2), 181-200.

Farida, Yusriati Nur, Yuli Prasetyo, dan Eliada Herwiyanti. (2010). Pengaruh Penerapan Corporate Governance Terhadap Timbulnya Earnings Management Dalam Menilai Kinerja Keuangan Pada Perusahaan Perbankan di Indonesia. Jurnal Bisnis dan Akuntansi, Vol. 12 No. 2, Agustus, 2010, hlm: 69-80.

Firnanti, F. (2017). Pengaruh Corporate Governance , Dan Faktor-Faktor Lainnya Terhadap, 19(1), 66-80.

Guna, Welvin I, dan A. Herawaty. (2010). Pengaruh Mekanisme Good Corporate Governance, Independensi Auditor, Kualitas Audit, dan Faktor Lainnya Terhadap Manajemen Laba. Jurnal Bisnis dan Akuntansi, Vol. 12 No. 1, April, 2010, hlm: 53-68.

Gunawan, I. K., Ari, N., Darmawan, S., Gusti, I., Purnamawati, A., Akuntansi, J., ... Leverage, L. (2015). Pengaruh Ukuran Perusahaan, Profitabilitas, Dan 
Leverage Terhadap Manajemen Laba Pada Perusahaan Manufaktur Yang Terdaftar Di Bursa Efek Indonesia (Bei). Journal S1 Ak Universitas Pendidikan Ganesha Jurusan Akuntansi Program S1, 3(1).

IDX. PT Bursa Efek Indonesia. www.idx.co.id. Diakses 30 September 2018.

Investment, Indonesia. (2018). Mining Index. https://www.indonesiainvestments.com/id/finance/stocks-bonds/jakarta-composite-indexihsg/mining-index/item889?. Diakses 30 September 2018.

Kusumawardhani, I. (2012). Pengaruh Corporate Governance, Struktur Kepemilikan, Dan Ukuran Perusahaan Terhadap Manajemen Laba, 41-54.

Komite Nasional Kebijakan Governance (KNKG). (2006). Pedoman Umum Good Corporate Governance Indonesia. Jakarta.

Lidiawati, N., \& Asyik, N. F. (2016). Pengaruh Kualitas Audit, Komite Audit, Kepemilikan Institusional, Ukuran Perusahaan Terhadap Manajemen Laba. Jurnal Ilmu Dan Riset Akuntansi, 5(5).

Midiastuty, P., dan Mas'ud Machfoedz. (2003). Analisis Hubungan Mekanisme Corporate Governance dan Indikasi Manajemen Laba. Simposium Nasional Akuntansi VI.

Murhadi, Werner R. (2009). Studi Pengaruh Good Corporate Governance Terhadap Praktik Earning Management Pada Perusahaan Terdaftar di PT Bursa Efek Indonesia. Jurnal Manajemen dan Kewirausahaan, 2 (1): 1-10.

Octavianto, D., dan Widagdo, K. (2014). Pengaruh Good Corporate Governance Terhadap, 3(2012), 1-9.

Okezone. (2016). Kasus PT Timah Tbk. https://economy.okezone.com/read/2016/01/27/278/1298264/direksi-timahdituding-manipulasi-laporan-keuangan. Diakses 30 September 2018.

Prabaningrat, I. G. A. A., \& Widanaputra, A. A. G. (2015). Pengaruh Good Corporate Governance dan Konservatisme Akuntansi Pada Manajemen Laba. E-Jurnal Akuntansi Universitas Udayana Jurnal Akuntansi Universitas Udayana, 10(3), 663-676.

Prastiti, A., \& Meiranto, W. (2013). Pengaruh Karakteristik Dewan Komisaris dan Komite Audit terhadap Manajemen Laba. Jurnal Akuntansi, 2(4), 1-12.

Putra, I. N. W. A. (2010). Manajemen laba: perilaku manajemen. Universitas Udayana, 1-21. 
Putra, P. A., Sinarwati, N. K., Ari, N., dan Darmawan, S. (2014). Pengaruh Asimetri Informasi dan Ukuran Perusahaan terhadap Praktek Manajemen Laba Pada Perusahaan manufaktur yang terdaftar di Bursa Efek Indonesia. EJournal S1 Ak Universitas Pendidikan Ganesha Jurusan Akuntansi Program S1, 2(1).

Radzi, Siti N. J. Mohd, Md. Aminul Islam, and Suraiya Ibrahim. (2011). Earning Quality in Public Listed Companies: A Study on Malaysia Exchange for Securities Dealing and Automated Quotation. International Journal of Economics and Finance, Vol. 3 No. 2, Mei 2011, hlm: 233-244.

Rafdan Anggana, G., dan Prastiwi, A. (2013). Analisis Pengaruh Corporate Governance Terhadap Praktik Manajemen Laba (Studi pada Perusahaan Manufaktur di Indonesia). Diponegoro Journal of Accounting, 2(3), 1-12.

Sulistyanto, Sri H. (2008). Manajemen Laba: Teori dan Model Empiris. Jakarta: Grasindo.

Ujiyantho, Arief Muh dan Bambang Agus Pramuka. (2007). Mekanisme Corporate Governance, Manajemen Laba dan Kinerja Keuangan. Simposium Nasional Akuntansi X.

Wahyono, R. E. S. (2012). Pengaruh Corporate Governance Terhadap Manajemen Laba Di Industri Perbankan Indonesia, 1(12), 1-21.

Watiningsih, Henggar. (2011). Pengaruh Pengungkapan Laporan Keuangan Sukarela, Leverage, dan Set Kesempatan Investasi Terhadap Manajemen Laba. Jurnal Ekonomi dan Bisnis, Vol. 5 No. 3, November, 2011, hlm: 237244.

Zeptian, A., \& Rohman, A. (2013). Analisis Pengaruh Penerapan Corporate Governance, Struktur Kepemilikan, Dan Ukuran Perusahaan. Diponegoro Journal of Accounting, 2, 1-11. 